\title{
Epidermal growth factor receptor structural alterations in gastric
}

\section{cancer}

\author{
Cátia Moutinho ${ }^{\dagger 1}$, Ana R Mateus ${ }^{\dagger 1,2}$, Fernanda Milanezi ${ }^{1}$, Fátima Carneiro ${ }^{1,3}$, \\ Raquel Seruca*1,3 and Gianpaolo Suriano*1,3
}

Address: ${ }^{1}$ Instituto de Patologia e Imunologia Molecular da Universidade do Porto (IPATIMUP), 4200-465 Porto, Portugal, ${ }^{2}$ Technische Universität München, Klinikum rechts der Isar, Institut für Allgemeine Pathologie und Pathologische Anatomie, D-81675 München, Germany and ${ }^{3}$ Faculdade de Medicina da Universidade do Porto, 4200-465 Porto, Portugal

Email: Cátia Moutinho - catiamoutinhos@hotmail.com; Ana R Mateus - amateus@ipatimup.pt; Fernanda Milanezi - mmilanezi@ipatimup.pt; Fátima Carneiro - fcarneiro@ipatimup.pt; Raquel Seruca* - rseruca@ipatimup.pt; Gianpaolo Suriano* - gsuriano@ipatimup.pt

* Corresponding authors †Equal contributors

Published: 16 January 2008

BMC Cancer 2008, 8:10 doi:10.1186/147|-2407-8-10
Received: 7 August 2007

Accepted: 16 January 2008

This article is available from: http://www.biomedcentral.com/I47I-2407/8/10

(C) 2008 Moutinho et al; licensee BioMed Central Ltd.

This is an Open Access article distributed under the terms of the Creative Commons Attribution License (http://creativecommons.org/licenses/by/2.0), which permits unrestricted use, distribution, and reproduction in any medium, provided the original work is properly cited.

\begin{abstract}
Background: EGFR overexpression has been described in many human tumours including gastric cancer. In NSCLC patients somatic EGFR mutations, within the kinase domain of the protein, as well as gene amplification were associated with a good clinical response to EGFR inhibitors. In gastric tumours data concerning structural alterations of EGFR remains controversial. Given its possible therapeutic relevance, we aimed to determine the frequency and type of structural alterations of the EGFR gene in a series of primary gastric carcinomas.

Methods: Direct sequencing of the kinase domain of the EGFR gene was performed in a series of 77 primary gastric carcinomas. FISH analysis was performed in 30 cases. Association studies between EGFR alterations and the clinical pathological features of the tumours were performed.

Results: Within the 77 primary gastric carcinomas we found two EGFR somatic mutations and several EGFR polymorphisms in exon 20. Six different intronic sequence variants of EGFR were also found. Four gastric carcinomas showed balanced polysomy or EGFR gene amplification. We verified that gastric carcinoma with alterations of EGFR (somatic mutations or copy number variation) showed a significant increase of tumour size $(p=0.0094)$ in comparison to wild-type EGFR carcinomas.

Conclusion: We demonstrate that EGFR structural alterations are rare in gastric carcinoma, but whenever present, it leads to tumour growth. We considered that searching for EGFR alterations in gastric cancer is likely to be clinically important in order to identify patients susceptible to respond to tyrosine kinase inhibitors.
\end{abstract}

\section{Background}

Gastric cancer remains the second leading cause of cancer death worldwide [1] a scenario that highlights the need for more specific and efficient therapies. The exact mech- anisms underlying gastric carcinogenesis are not yet fully understood, but evidence points to an association with pathways involved in developmental processes [2]. Key molecules of these pathways are the receptor tyrosine 
kinases (RTKs), which are found to be aberrantly activated or overexpressed in a variety of tumours and therefore represent promising targets for therapeutical intervention.

The members of the RTK superfamily of ERBB receptors are glycoproteins that consist of an extracellular domain where the binding of ligands takes place, a short lipophilic transmembrane domain, and an intracellular domain carrying the tyrosine kinase activity $[3,4]$. They are expressed in several tissues of epithelial, mesenchymal and neuronal origin, where they play pivotal roles in development, proliferation and differentiation. Deregulated expression of ERBB molecules, namely ERBB2, has been implicated in the development of numerous types of tumours, including gastric tumours. In gastric carcinoma it has been shown that ERBB2 overexpression is driven by gene amplification and is associated to carcinomas with high invasive potential [5]. ERBB1, better known as epidermal growth factor receptor (EGFR), overexpression has been described in many human tumours, including lung, colon, breast, prostate, brain, head and neck, thyroid, ovarian, bladder, kidney and also stomach cancer [6-11], and has been correlated to advanced tumour stage and poor clinical outcome. Very recently, we demonstrated that EGFR activation is associated to loss of function of Ecadherin, in vitro [12].

The mechanisms for oncogenic conversion of EGFR in cancer include amplified copy number, structural rearrangements of the receptor, and activating mutations [13]. EGFR mutations cluster in the kinase domain of EGFR (exons 18-21), and cause ligand-independent activation of the receptor, representing possible targets for therapeutical intervention. In this regard, somatic EGFR mutations as well as gene amplification in patients with non-small cell lung cancer (NSCLC) highly correlate with the clinical response to tyrosine kinase inhibitors $[14,15]$.

In gastric tumours, data concerning structural alterations of EGFR remains controversial. Given its possible therapeutic relevance, in the present study we aimed to clarify the relevance of EGFR structural alterations in gastric carcinogenesis by analyzing a series of primary gastric carcinomas for copy number and mutations in the tyrosine kinase domain (exons 18-21) of the EGFR gene.

\section{Methods}

\section{Case selection and histopathological classification of the tumours}

Representative blocks of 77 formalin-fixed, paraffin embedded human gastric primary tumours were retrieved from the Department of Pathology of the Hospital S. João, after informed consent of the patients. Patients were informed that tumour material would be used for research purposes only. None of the patients included in the present series had a family history of gastric cancer. H\&Estained sections were used to categorize tumours according to the classifications of Lauren and Ming. Penetration of the gastric wall and the presence and localization of lymph node metastases were recorded for all patients using standard criteria for pathological staging. Orceinstained sections were used for the detection of vascular invasion.

\section{EGFR Mutation Screening}

Genomic DNA was extracted from $10 \mu \mathrm{m}$ section after microdissection of the tumour areas to ensure a purity of at least $70 \%$ of neoplastic cells. DNA extraction was performed using the Genomic DNA Purification Kit (Gentra System) according to the manufacturer's protocol. Exonspecific primers were designed and DNA was subjected to PCR amplification of exons 18, 19, 20 and 21. The four EGFR exons code for the tyrosine kinase domain of EGFR. Primer sequences are shown in Table 1.

PCR products were run on a $2 \%$ agarose gel and PCR amplified bands were extracted from the gel with the Gel Band Purification Kit (GE Healthcare). Samples were then purified and sequenced using the ABI Prism dGTP BigDye Terminator Ready Reaction Kit (Perkin Elmer, Foster City, CA) following manufacture's instruction and an ABI Prism 3100 Genetic Analyser (Perkin Elmer, Foster City, $\mathrm{CA})$. The results were analysed using 3100 data collection software. Sequencing was performed in both strands. In cases with suspected mutations PCR amplification was repeated and the sample was re-sequenced to rule out PCR artefacts.

\section{EGFR Copy Number Variation Screening}

The paraffin blocks were sectioned at $5 \mu \mathrm{m}$ and tissue sections were dried at $60^{\circ} \mathrm{C}$ for 30 minutes. The slides were deparaffinised and washed followed by a pre-treatment and a digestion step using pepsin and finally dehydrated. The LSI EGFR Dual Color Probe-Hyb Set (VYSIS ${ }^{\circledR}$ ), optimized to detect the band region $7 \mathrm{p} 12$ in spectrum orange and the centromere of chromosome 7 (7p11.1-q11.1,

Table I: Primers used for PCR amplification of the EGFR kinase domain

\begin{tabular}{|c|c|c|c|}
\hline Exon & & Primer Sequence & $\begin{array}{c}\text { PCR } \\
\text { product } \\
\text { size (bp) }\end{array}$ \\
\hline \multirow[t]{2}{*}{ Exon 18} & Forward & TGGGCCATGTCTGGCACTGC & 283 \\
\hline & Reverse & ACAGCTTGCAAGGACTCTGG & \\
\hline \multirow[t]{2}{*}{ Exon 19} & Forward & TCACTGGGCAGCATGTGGCA & 241 \\
\hline & Reverse & CAGCTGCCAGACATGAGAAA & \\
\hline \multirow[t]{2}{*}{ Exon 20} & Forward & CСTTCTGGCCACCATGCGAA & 295 \\
\hline & Reverse & CGCATGTGAGGATCCTGGCT & \\
\hline \multirow[t]{2}{*}{ Exon 21} & Forward & ATTCGGATGCAGAGCTTCTT & 265 \\
\hline & Reverse & CCTGGTGTCAGGAAAATGCT & \\
\hline
\end{tabular}


D7Z1 locus) in spectrum green, both in interphase nuclei and on metaphase chromosomes, was used. Five $\mu \mathrm{l}$ of the probe were applied to each slide. The denaturation was performed at $80^{\circ} \mathrm{C}$ for 8 minutes followed by hybridization on a humid chamber at $37^{\circ} \mathrm{C}$ for 16 hours. After hybridization, slides were washed and incubated with $4^{\prime}-$ 6-Diamidino-2-phenylindole (DAPI) for nuclear staining. For evaluation, sixty to 100 intact interphase nuclei were analysed by two independent observers in order to score the signals for the chromosome 7 centromere and the EGFR gene. Surrounding lymphocytes and normal mucosa were used as internal quality control for the assays. At least two or three representative areas of the neoplastic cells were selected, under a $100 \times / 200 \times$ amplification field, to count the nuclei signals. After an overview under a $400 \times$ amplification, the signals were then counted using immersion oil $(1000 \times)$.

\section{Statistical analysis}

Association studies between EGFR alterations and the clinicopathological features of the cases were performed only in 30 cases (tumours analysed for EGFR mutations and EGFR copy number variation). Statistical analyses were assessed by the $\mathrm{x} 2$ test or Student's $t$ test. A $p$ value of $<0.05$ was considered statistically significant.

\section{Results}

\section{EGFR Mutation Screening}

From the 77 gastric carcinomas analysed, EGFR mutations in exons $18-21$ were detected in $2.6 \%(2 / 77)$ of the cases (Fig. 1A). One mutation belonged to exon 20 and was a missense mutation ( $2300 \mathrm{C}>\mathrm{T}$ ) leading to the substitution of the Alanine 767 for a Valine. The second mutation affected exon 21 and was a missense mutation (2524 $A>G$ ) leading to the substituition of the Asparagine 842 for an Aspartic acid. None of the mutations were previously described. No sequence alterations were found in exons 18 and 19.

Several EGFR polymorphisms were found in exon 20 (Table 2). The polymorphism 2361G>A Gln787Gln, previously described by $\mathrm{Mu}$ et al [16], was present in $55.8 \%$ (43/77) of the cases, and in nine of the 43 cases in a homozygous state. We screened 50 normal controls and the $2361 \mathrm{G}>\mathrm{A}$ Gln787Gln was present in $82 \%$ of the controls (41/50). Two other EGFR silent mutations (the 2301 C>T Ala767Ala and the $2415 \mathrm{C}>\mathrm{T}$ His805His) were found in exon 20, none of them previously described. Both alterations were found in a single case and were absent in normal controls.

We found six different sequence variants localized in intronic regions of EGFR, two of them previously described in Ensembl [17].

\section{EGFR Copy Number Variation Screening}

The analysis of EGFR copy number, as assessed by fluorescence in situ hybridization (FISH), was only possible in 30 of the 77 cases analysed for EGFR mutations. All EGFR signals were compared to signals for centromeric probes for chromosome 7. More than 2.0 EGFR copies per cell (balanced polysomy or gene amplification) were detected in $13.3 \%(4 / 30)$ of the cases. Of the four cases showing more than 2 copies of EGFR per chromosome 7, three had increased copy number due to polysomy and one had gene amplification, a diffuse gastric carcinoma, exhibiting
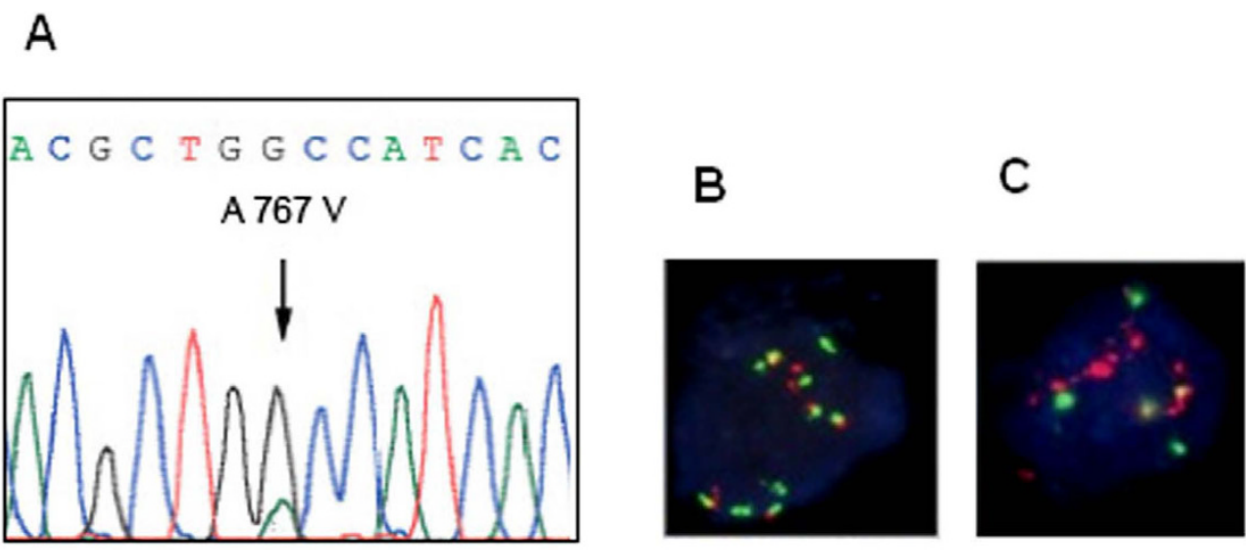

\section{Figure I}

Structural alterations in EGFR. (A) Direct sequencing showing one of the mutations found in the kinase domain of EGFR missense mutation $(2300 \mathrm{C}>\mathrm{T})$ in exon 20 , leading to the substitution of the Alanine 767 for a Valine. (B) Diffuse gastric carcinoma with EGFR increased copy number caused by chromosome 7 polysomy. (C) Neoplastic cells exhibiting gene amplification with the formation of clusters with numerous signals for EGFR. 
Table 2: Sequence alterations found by direct sequencing

\begin{tabular}{|c|c|c|c|c|}
\hline & Alteration & Type & Frequency & References \\
\hline \multicolumn{5}{|l|}{ Exon 18} \\
\hline & $2184+19 \mathrm{G}>A$ & Intronic variant & $2 / 77$ & $\begin{array}{l}\text { Ensembl } \\
\text { SNP rs I7337I07 (dbSNPI26) [17] }\end{array}$ \\
\hline \multicolumn{5}{|l|}{ Exon 19} \\
\hline & $2185-9 \mathrm{C}>\mathrm{G}$ & Intronic variant & $\mathrm{I} / 77$ & Not yet described \\
\hline & $2283+1 \mid G>A$ & Intronic variant & $1 / 77$ & Not yet described \\
\hline & $2283+47 \mathrm{G}>\mathrm{A}$ & Intronic variant & $\mathrm{I} / 77$ & Not yet described \\
\hline & $2283+49 \mathrm{C}>\mathrm{T}$ & Intronic variant & $\mathrm{I} / 77$ & Not yet described \\
\hline \multicolumn{5}{|l|}{ Exon 20} \\
\hline & $2284-60 \mathrm{C}>\mathrm{T}$ & Intronic variant & $2 / 77$ & $\begin{array}{l}\text { Ensembl } \\
\text { SNP rs I024|45I (dbSNPI26) [17] }\end{array}$ \\
\hline & $2300 \mathrm{C}>\mathrm{T}$ & Missense Ala $767 \mathrm{Val}$ & $\mathrm{I} / 77$ & Not yet described \\
\hline & $2301 \mathrm{C}>\mathrm{T}$ & Silent Ala $767 \mathrm{Ala}$ & $\mathrm{I} / 77$ & Not yet described \\
\hline & $236 I G>A$ & Silent Gln 787 Gln & $43 / 77$ & {$[16]$} \\
\hline & $24 I 5 C>T$ & Silent His $805 \mathrm{His}$ & $1 / 77$ & Not yet described \\
\hline \multicolumn{5}{|l|}{ Exon 21} \\
\hline & $2524 A>G$ & Missense Asn 842 Asp & $\mathrm{I} / 77$ & Not yet described \\
\hline
\end{tabular}

the formation of clusters with numerous signals for $E G F R$

(Fig. 1B, C).

\section{EGFR structural alterations and clinicopathologic parameters of the patients and tumours}

Table 3 shows the statistical associations between EGFR alterations and the clinicopathologic characteristics of the patients and tumours. When comparing gastric carcinoma harbouring EGFR alterations with carcinomas with normal EGFR status or copy number, we observed a significant association between EGFR structural alterations and increased tumour size. $(p=0.0094)$. No significant associations were found between EGFR alterations and other clinicopathologic parameters of the patients and tumours,

Table 3: Association of EGFR gene alterations with clinicopathological parameters

\begin{tabular}{|c|c|c|c|c|}
\hline \multirow[t]{2}{*}{ Clinicopathological parameters } & \multicolumn{4}{|c|}{ EGFR status } \\
\hline & Amplification/mutation $(n=6)$ & Normal $(n=24)$ & Total $(n=30)$ & $p$ value \\
\hline $\operatorname{Sex}(F / M)$ & $\mathrm{I} / 5$ & $10 / 14$ & $11 / 19$ & 0.2557 \\
\hline Age (SD) & $62.3 \pm \mid 4,1$ & $56.3 \pm 16.8$ & $57.5 \pm 16.2$ & 0.4271 \\
\hline Tumour localization & & & & 0.8548 \\
\hline Proximal & 3 & 11 & 14 & \\
\hline Distal & 3 & 13 & 16 & \\
\hline Size (SD) & $11.6 \pm 9.8$ & $5.8 \pm 2.0$ & $6.9 \pm 5.0$ & $* 0.0094$ \\
\hline Lauren's classification & & & & 0.1261 \\
\hline Intestinal & 1 & 12 & 13 & \\
\hline Diffuse & 5 & 9 & 14 & \\
\hline Atypical & 0 & 3 & 3 & \\
\hline Wall penetration & & & & 0.4642 \\
\hline Early (TI) & 0 & 2 & 2 & \\
\hline Advanced (T2-T4) & 6 & 22 & 28 & \\
\hline Vascular Invasion & & & & 0.7125 \\
\hline Absent (N0) & 3 & 14 & 17 & \\
\hline Present $(N=1)$ & 3 & 10 & 13 & \\
\hline Lymph node metastasis & & & & 0.1921 \\
\hline Absent & 1 & 11 & 12 & \\
\hline Present & 5 & 13 & 18 & \\
\hline Staging & & & & 0.3845 \\
\hline I & 1 & 7 & 8 & \\
\hline II & 0 & 5 & 5 & \\
\hline III & 5 & 11 & 16 & \\
\hline IV & 0 & 1 & 1 & \\
\hline
\end{tabular}


namely gender and age of the patients, tumour localization, histological type, wall penetration, the presence of lymph node metastasis, vascular invasion and tumour staging of the tumour.

\section{Discussion}

EGFR gene is located on chromosome 7p12 and codes for a $170-K D a$ receptor, present in the membrane of cells as an inactive monomers. Upon ligand binding to the extracellular domain, the receptor undergoes conformational changes, dimerises and becomes autophosphorylated in key tyrosine residues in the intracellular tyrosine kinase (TK) domain. This leads to the activation of downstream pathways which control cell survival, inhibition of apoptosis and proliferation [18].

Much attention has been drawn to the oncogenic effect of EGFR and most of all to success of EGFR target therapies, which are well established for non small cell lung carcinomas. The role of EGFR in gastric cancer is very controversial. Some authors reported that EGFR is highly expressed in gastric cancer, suggesting its suitability as a target for receptor tyrosine kinase inhibitors $[19,20]$. Conversely, Takehana and colleagues reported that overexpression of epidermal growth factor receptor is a rare event in gastric carcinoma [21] and occurs predominantly due to EGFR gene amplification, confirming results from previous studies [22-24]. EGFR mutations in primary gastric carcinoma or gastric cancer cell lines were never reported [2527]; nevertheless we recently showed that hereditary diffuse gastric cancer associated E-cadherin germline missense mutations lead to increased EGFR activity.

On this basis, we considered that searching for EGFR alterations in gastric cancer might have been important to identify therapy susceptible cases.

Here we report the presence of EGFR increased copy number in $13.3 \%$ of the 30 cases in which FISH analysis was possible. Of the four cases with increased copy number, just one presented gene amplification, whereas the remaining 3 cases showed polysomy of chromosome 7. These results match previous reports investigating the EGFR copy number in gastric cancer [22-24]. The mutational analysis of the kinase domain of EGFR revealed the presence of mutations in $2.6 \%$ of 77 gastric carcinomas. The identified mutations were of the missense type and were present in exons 20 and 21 of the EGFR gene. None of the identified mutations had been previously described and their functional significance is not yet assessed. However, due to their localization in the kinase domain of EGFR, it is tempting to speculate that they affect the activity of the receptor and therefore patients harbouring these EGFR mutations may benefit from tyrosine kinase inhibitors as therapeutic approach.
Besides these mutations found, other sequence alterations were identified, all clustering in exon 20. The EGFR polymorphism $2361 \mathrm{G}>\mathrm{A}$ (previously described in Ensembl) occurs in a high percentage of cases and in normal controls. In contrast, the other two not yet described silent variants in exon 20 (2301 C>T, $2415 \mathrm{C}>\mathrm{T})$ were absent in normal controls. In addition to these EGFR sequence variants in coding regions, we have also identified variations in the intronic sequence flanking exons 18, 19 and 20, but their functional effect remains unclear.

The correlation of the clinical parameters for the cases for which both mutation and FISH analysis was possible, showed a significant association between EGFR alterations and tumour size. Interestingly, all cases with alterations in EGFR (amplification/mutation) were carcinomas already invading the basal membrane and spreading into the gastric wall (T2-T4), suggesting that alterations of this gene may confer an invasive behaviour to neoplastic cells.

However, this hypothesis needs to be clarified by further studies, since we did not verify a statistically significant correlation between EGFR alterations and invasion in the gastric wall ( $\mathrm{p}=0.4642)$, as we have just analised a very low number of early gastric carcinomas $(n=2)$ in our series. Both results are in agreement with the reports of Hirono et al., 1995 [23] and Tsugawa et al., 1998 [24], suggesting that EGFR is involved in tumour growth and activating alterations may be a late event involved in tumour progression.

Although no other statistically significant association was found, it is interesting to notice that EGFR alterations occur mainly in carcinomas of the diffuse type. The presence of EGFR alterations in diffuse carcinomas is in contrast to what previously observed for other members of the ERBB receptor family in gastric cancer. In gastric carcinoma ERBB2 amplification was detected preferentially in intestinal carcinomas of the stomach [5].

\section{Conclusion}

In conclusion, in this study we demonstrated that EGFR activating alterations are not a frequent event in gastric carcinogenesis. Alterations preferentially appear in gastric carcinomas of the diffuse subtype and are associated to tumour size. Despite the low frequency of EGFR alterations, our results also indicate that there is a restricted group of selected gastric patients that might benefit from non conventional therapies, including pharmacological inhibitors of the EGFR receptor.

\section{Competing interests}

The author(s) declare that they have no competing interests. 


\section{Authors' contributions}

RS and GS were responsible for study concept and design, as well as study supervision. CM carried out the molecular genetic studies and participated in the drafting of the manuscript. FM and FC were responsible for analysis and interpretation of data. ARM collected the data and performed the drafting of the manuscript. RS and GS did the critical revision of the manuscript for important intellectual content. All authors read and approved the final manuscript.

\section{Acknowledgements}

This study was funded by grants from the Fundação para a Ciência e a Tecnologia, Portugal (SFRH/BD/I6747/2004, POCI/SAU - OBS/57670/2004 and PTDC/SAU - OBD/64319/2006).

\section{References}

I. Pisani P, Parkin DM, Bray F, Ferlay J: Estimates of the worldwide mortality from 25 cancers in 1990. Int J Cancer 1999, 83(I):18-29.

2. Abate-Shen C: Deregulated homeobox gene expression in cancer: cause or consequence? Nat Rev Cancer 2002, 2(1 0):777-785.

3. Ullrich A, Schlessinger J: Signal transduction by receptors with tyrosine kinase activity. Cell I990, 6 I(2):203-2I 2.

4. Klapper LN, Kirchbaum MH, Sela M, Yarden Y: Biochemical and clinical implications of the ErbB/HER signaling network of growth factor receptors. Adv Cancer Res 2000, 77:25-79.

5. David L, Seruca R, Nesland JM, Soares P, Sansonetty F, Holm R, Borresen AL, Sobrinho-Simoes M: c-erbB-2 expression in primary gastric carcinomas and their metastases. Mod Pathol 1992, 5(4):384-390.

6. Berger MS, Greenfield C, Gullick WJ, Haley J, Downward J, Neal DE, Harris AL, Waterfield MD: Evaluation of epidermal growth factor receptors in bladder tumours. $B r J$ Cancer 1987, 56(5):533-537.

7. Gullick WJ: Prevalence of aberrant expression of the epidermal growth factor receptor in human cancers. $\mathrm{Br}$ Med Bull |99|, 47:87-98.

8. Lemoine NR, Hughes CM, Gullick WJ, Brown CL, Wynford-Thomas $D$ : Abnormalities of the EGF receptor system in human thyroid neoplasia. Int J Cancer I99I, 49(4):558-56I.

9. Libermann TA, Nusbaum HR, Razon N, Kris R, Lax I, Soreq H, Whittle N, Waterfield MD, Ullrich A, Schlessinger J: Amplification, enhanced expression and possible rearrangement of EGF receptor gene in primary human brain tumours of glial origin. Nature 1985, 313:144-147.

10. Salomon DS, Brandt R, Ciardiello F, Normanno N: Epiderma growth factor-related peptides and their receptors in human malignancies. Crit Rev Oncol Hematol 1995, 19:183-232.

II. Tillotson JK, Rose DP: Endogenous secretion of epidermal growth factor peptides stimulates growth of DU I 45 prostate cancer cells. Cancer Lett 1991, 60:109-112.

12. Mateus AR, Seruca R, Machado JC, Keller G, Oliveira MJ, Suriano G, Luber B: EGFR regulates RhoA-GTP dependent cell motility in E-cadherin mutant cells. Hum Mol Genet 2007, 16(13): 1639-1647.

13. Hynes NE, Lane HA: ERBB receptors and cancer: The complexity of targeted inhibitors. Nat Rev Cancer 2005, 5:34I-354.

14. Lynch TJ, Bell DW, Sordella R, Gurubhagavatula S, Oimoto RA, Brannigan BW, Harris PL, Haserlat SM, Supko JG, Haluska FG, Louis DN, Christiani DC, Settleman J, Haber DA: Activating mutations in the epidermal growth factor receptor underlying responsiveness of non-small-cell lung cancer to gefitinib. N EnglJ Med 2004, 350:2129-2139.

15. Paez JG, Janne PA, Lee JC, Tracy S, Greulich H, Gabriel S, Herman P, Kaye FJ, Linderman N, Boggon T], Naoki K, Sasaki H, Fujii Y, Eck MJ, Sellers WR, Johnson BE, Meyerson M: EGFR mutations in lung cancer: correlation with clinical response to gefitinib therapy. Science 2004, 04:1497-1500.
16. Mu XL, Li LY, Zhang XT, Wang MZ, Feng RE, Cui OC, Zhou HS, Guo $B Q$ : Gefitinib-sensitive mutations of the epidermal growth factor receptor tyrosine kinase domain in chinese patients with non-small cell lung cancer. Clin Cancer Res 2005, I I ( 2):4289-4294.

17. Esemble Genome Browser [http://www.ensembl.org]

18. Schlessinger J: Ligand-induced, receptor-mediated dimerization and activation of EGF receptor. Cell 2002, I I 0:669-672.

19. Hirao T, Sawada H, Koyama F, Watanabe A, Yamada Y, Sakaguchi T, Tatsumi M, Fujimoto H, Emoto K, Narikiyo M, Oridate N, Nakano H: Antisense epidermal growth factor receptor delivered by adenoviral vector blocks tumor growth in human gastric cancer. Cancer Gene Ther 1999, 6(5):423-427.

20. Becker JC, Muller-Tidow C, Stolte M, Fujimori T, Tidow N, llea AM, Brandts C, Tickenbrock L, Serve H, Berdel WE, Domschke W, Pohle $\mathrm{T}$ : Acetylsalicylic acid enhances antiproliferative effects of the EGFR inhibitor gefitinib in the absence of activating mutations in gastric cancer. Int I Oncol 2006, 29(3):6I5-623.

21. Takehana T, Kunitomo K, Suzuki S, Kono K, Fujii H, Matsumoto Y, Ooi A: Expression of epidermal growth factor receptor in gastric carcinomas. Clin Gastroenterol Hepatol 2003, I (6):438-445.

22. Tokunaga A, Onda M, Okuda T, Teramoto T, Fujita I, Mizutani T, Kiyama T, Yoshiyuki T, Nishi K, Matsukura N: Clinical significance of epidermal growth factor (EGF), EGF receptor, and cerbB-2 in human gastric cancer. Cancer 1995, 75(6 Suppl): |4|8-|425.

23. Hirono Y, Tsugawa K, Fushida S, Ninomiya I, Yonemura Y, Miyazaki I, Endou Y, Tanaka M, Sasaki T: Amplification of epidermal growth factor receptor gene and its relationship to survival in human gastric cancer. Oncology 1995, 52(3): I82-188.

24. Tsugawa K, Yonemura Y, Hirono Y, Fushida S, Kaji M, Miwa K, Miyazaki I, Yamamoto $\mathrm{H}$ : Amplification of the c-met, c-erbB-2 and epidermal growth factor receptor gene in human gastric cancers: correlation to clinical features. Oncology 1998 , 55(5):475-48।.

25. Mammano E, Belluco C, Sciro M, Mencarelli R, Agostini M, Michelotto M, Marchet A, Nitti D: Epidermal growth factor receptor (EGFR): mutational and protein expression analysis in gastric cancer. Anticancer Res 2006, 26(5A):3547-3550.

26. Dragovich T, McCoy S, Fenoglio-Preiser CM, Wang J, Benedetti JK, Baker AF, Hackett CB, Urba SG, Zaner KS, Blanke CD, Abbruzzese $\mathrm{JL}$ : Phase II trial of erlotinib in gastroesophageal junction and gastric adenocarcinomas: SWOG 0127. J Clin Oncol 2006, 24(30):4922-4927.

27. Mimori K, Nagahara $\mathrm{H}$, Sudo $\mathrm{T}$, Ishii $\mathrm{H}$, Yamashita $\mathrm{K}$, Barnard GF, Mori $M$ : The epidermal growth factor receptor gene sequence is highly conserved in primary gastric cancers. J Surg Oncol 2006, 93(I):44-46.

\section{Pre-publication history}

The pre-publication history for this paper can be accessed here:

http://www.biomedcentral.com/1471-2407/8/10/prepub

Publish with Bio Med Central and every scientist can read your work free of charge

"BioMed Central will be the most significant development for disseminating the results of biomedical research in our lifetime. "

Sir Paul Nurse, Cancer Research UK

Your research papers will be:

- available free of charge to the entire biomedical community

- peer reviewed and published immediately upon acceptance

- cited in PubMed and archived on PubMed Central

- yours - you keep the copyright
BiolMedcentral 